\title{
EX-POST EVALUATION OF LOCAL ACTION GROUPS IN LEADER PROGRAMME (VISEGRÁD COUNTRIES)
}

\author{
EX-POST HODNOCENÍ MÍSTNÍCH AKČNÍCH SKUPIN V \\ PROGRAMU LEADER (ZEMĚ VISEGRÁDSKÉ ČTYŘKY) \\ Zuzana DVOŘÁKOVÁ LÍŠKOVÁa , Renata KLUFOVÁa, Michael ROST ${ }^{\mathrm{a}}$
}

aFaculty of Economics, University of South Bohemia, zuli@ef.jcu.cz, klufova@ef.jcu.cz,rost@ef.jcu.cz

Cite this article: Dvořáková Líšková, Z. Klufová, R., Rost M. (2019). Ex-post Evaluation of Local Action Groups in LEADER Programmes. Deturope. 11(1), 4-20.

\begin{abstract}
The LEADER approach has prompted the EU to become more interested in its ability to address development issues through new forms of partnership. One of the examples of these partnerships is a "local action group" (LAG), which emerges as an institutionalized partnership between the public and private sectors. The aim of the contribution is the ex-post evaluation of the LEADER implementation mechanism at LAGs in the V4 countries (2007-2013). The first step was to obtain the statistical data, the theoretical knowledge and the legislative framework for implementing LEADER in all V4 countries. Subsequently, a comparison of the quantitative aspects of LEADER implementation in the V4 states was carried out at the end of the programming period 2007-2013 with the planned status in the Rural Development Programs. The second step was to design an evaluation framework for the LEADER approach implementation mechanism based on the Tvrdoňová methodology (2014). An important methodical step was to define the seven basic functions of the program and to assign so-called benchmarks. Their presence represents the optimal state of implementation of the program. By linking the functions with the individual boot steps, the implementation matrix was created. Benchmarking was conducted in the form of skype interviews at the national level of the LAG (management of the national networks of LAGs in the V4 countries). Ex-post evaluation subsequently led to the formulation of conclusions and recommendations.
\end{abstract}

Keywords: local action groups, implementation, program LEADER, Visegrad countries

\begin{abstract}
Abstrakt
Př́istup LEADER vyvolal vEU velký zájem pro svou schopnost zabývat se problémy rozvoje prostřednictvím nových forem partnerství. Jeden z př́kladů těchto partnerství představuje "místní akční skupina" (MAS), jež vzniká jako institucionalizované partnerství veřejného a soukromého sektoru. Cílem příspěvku je ex-post hodnocení implementačního mechanizmu programu LEADER na MAS ve státech V4 (v období 2007-2013). Prvním krokem bylo získání statistických údajů, teoretických poznatků a legislativního rámce o implementaci LEADER ve všech státech V4. Následně byla realizována komparace kvantitativních aspektů implementace mechanizmu LEADER ve státech V4 na konci programového období 2007-2013 s plánovaným stavem v Programech rozvoje venkova. Druhým krokem bylo vytvoření evaluačního rámce pro mechanizmus realizace přístupu LEADER, vycházejícího z metodiky Tvrdoňová (2014). Důležitým metodickým krokem bylo definování sedmi základních funkcí programu a přiřazení tzv. benchmarks (kritérií úspěchu). Jejich př́tomnost představuje optimální stav implementace programu. Propojením funkcí s jednotlivými kroky zavádění programu vedlo k vytvoření implementační matice. Hodnocení kritérií úspěchu (benchmarks) probíhalo formou skypových rozhovorů na národní úrovni MAS (management národní sítě MAS ve státech V4). Ex-post hodnocení následně vedlo $\mathrm{k}$ formulování závěrů a doporučení.
\end{abstract}

Keywords: místní akční skupiny, implementace, program LEADER, země Visegrádské čtyřky 


\section{INTRODUCTION}

A view of European rural areas shows a situation full of contrasts, where some areas are developing and others are lagging behind. Rural areas on the outskirts of big cities offer their natural resources. Peripheral rural areas suffer from long distance from global markets and low population density makes access to public services more difficult. Most rural areas are within these extremes, trying, more or less successfully, to fulfil social and economic needs of their populations. Where they are successful, there is new optimism, and innovative public administration or self-government supporting decentralization. Local initiative and authorization of citizens to govern and exercise power is a model of the future. Effective selfgovernment is today open to the public-private sector partnerships based on partner networking. Rural areas showing this inclination are exactly those applying the bottom-up approach. Responsibility for the definition of objectives, procedures, measures, and projects as well as for their implementation is the preferred approach of those policies which OECD generally qualifies as "place-based” (Navarro, \& Cejudo, 2015).

\section{THEORETICAL BACKGROUND}

\section{History of LEADER Approach in Europe and LAG}

The main concept of the approach called Links between Actions for the Development of the Rural Economy (LEADER) says that thanks to the diversity of the European rural areas the development strategies are more effective if they are decided about and implemented by local players on the local level by clear and transparent procedures. According to Pollermann, Raue, and Schnaut (2014), the LEADER approach developed from the initiative of the European Commission of the early 1990s as a pilot project for support or integrated activities and/or development schemes programmed and implemented exclusively on the local level. One of the new Community initiatives was called LEADER I. The initiative was launched in 1991 with the aim to improve the development potential of rural areas by encouraging local initiatives, support for acquisition of the "know-how" for regional development, and extension of the "know-how" across the rural areas (Thelen, 1999). Many national programmes of rural development at that time did not consider wider rural interests yet, with the exception of the traditional primary economic areas, and were mainly managed by the up-to-bottom approach (Bache, 2004). That is why LEADER began to combine local actors and resources and answer various local questions (known as the integrated development approach) (High \& Nemes, 2007). The necessary local focus on development was achieved through local action groups 
(LAGs), consisting of representatives of the public, the private and the voluntary sector for the purpose of surveillance over the local approach (LEADER) implementation. In 1991, the "initiation" stage of the LEADER approach was implemented, working with 217 LAGs in the underdeveloped rural areas. That provided an opportunity for networking and idea and experience exchange. Total EU investment amounted to ECU 417 million, representing circa $1 \%$ of the overall Community framework support in this period. Before 1994 the LEADER II programme advanced to the "generalization" stage with nearly 1,000 LAGs (Copus, Shucksmith, Dax, \& Meredith, 2011).

As a much broader programme, LEADER II added cooperation and innovation as extraordinary programme dimensions, and together with networking permitted cross-border good practice sharing. In that period, a pilot LEADER was launched to test some new ideas. The initiative called LEADER + was launched in 2000 as one of the four initiatives together with URBAN, INTERREG, and EQUAL financed from the EU structural funds, and accessible in all rural areas, unlike LEADER I and II (Fałkowski, 2013).

The main and the basic functional unit in the context of the LEADER approach is the local action group (LAG), a grouping of the private and the public sector on the local level, which, for the partnership decision-making purpose, must include at least $50 \%$ of the private sector representatives including the civic and the non-profit sector, and maximum 50\% of the public sector representatives (Teilmann \& Thuesen, 2014). LAG is a legal entity with compulsory management bodies able to administer public funds and manage LAG activity. The population of the territory managed by a LAG must be higher than 10,000 and lower than 150,000 citizens. The support excludes municipalities with the population over 20,000. The area to which the strategy is to be applied must cover a continuous rural area including cadastral areas of all included municipalities within the territory applying for the subsidy, formed on the basis of the common interest principle. The territory must operate a local action group and have an integrated strategy of territorial development with clearly formulated priorities, measures, and activities. The strategy must at the same time include innovative approaches, i.e. stimulation and novelty approaches to territorial development (Kovács, 2004).

\section{Origins of LEADER programme in Visegrad countries}

The LEADER programme has been implemented in the Visegrad countries since early 2007. What must, however, be emphasized is that Visegrad countries had already possessed some experience in implementation of rural development policies. This experience was obtained in connection with the implementation of LEADER+ in the years 2004-2006 (except Slovakia) 
and other programmes and initiatives based on this approach, implemented before EU accession. All Visegrad countries had implemented pilot programmes before EU accession. In the Czech Republic this was the Rural Renewal Programme (2001-2003), financed from SAPARD3, and in Poland, there were several programmes and initiatives existing since midnineties, already implementing the bottom-up principle. The Foundation for Partnership in Environment Protection (Fundacja Partnerstwo dla Środowiska), has supported development and maintenance of partner groups since 1999. Partnership development in Poland has also been significantly supported by the Forum for Activation of Rural Areas (Forum Aktywizacji Obszarów Wiejskich), the Foundation of the Cooperation Fund (Fundacja Fundusz Współpracy) and the Agroline programme (2003-2006), which have prepared the rural communities for implementation of programmes of the LEADER type. The Agroline programme (since 2004) has been allocated small grants for training and information activities for potential LAG (Zajda, 2014).

In the case of pre-accession Slovakia, there were three programmes supporting the LEADER approach there. The first was represented by the Rural Development Fund (1999 - 2002), financed from PHARE4. The funds obtained within this initiative were used for multi-sectoral partnerships for development and implementation of local development strategies. The second pilot programme called "Support for Regional Development of the Banskobystrický Region" (2002-2003) was financed by the UK Government (Brković \& Hamada, 2013). The purpose was to develop suitable development strategies for the LEADER approach. In the years 20032004, thanks to the support of the UN development programme (UNDP), Slovakia could launch the Local Agenda 21 project. Its goal was also to support LEADER-like local development strategies (Milotová, 2011).

In pre-accession Hungary, there were two programmes preparing the country for the LEADER approach implementation. They were micro-regional programmes, financed from national funds and implemented in the period 1999 - 2002. The support focused not only on the preparation of local development plans and initiatives but also on the strengthening of partnerships and improvement of management capacities. The second project was the target rural development programme: The pilot LEADER programme (2001 - 2004) also excluded from the state budget. Measures implemented in the context of this initiative (regional situation analysis and local development plan implementation) were to prepare the country for implementation of LEADER + in future. 
The period 2007-2013 was the first programme period in which the V4 countries were engaged in the implementation of European policies from the very beginning (including the LEADER programme) on the same level as the other EU Member States.

As a consequence of differences between the individual EU countries and specific development conditions (including administrative, legal, social, economic and spatial conditions) these countries are modified in the sense of the particular objectives and implemented programme solutions in the context of LEADER (such as the expected results, LAG creation criteria, fund allocations, adopted implementation system etc.) (Oedl-Wieser, Strahl, \& Dax, 2010).

In Hungary, LEADER appeared to be a useful tool for the development of municipal infrastructure and public services (Póla, Chevalier, \& Maurel, 2015).

The LEADER approach implementation and its results must be related to the rural development programme development stage in the individual Visegrad Group countries. The necessary steps included national modification of EU regulations concerning populations in the tri-sectoral partnerships on the basis of the specifics of the rural areas in each country (Pollermann et al., 2014).

\section{DATA AND METHODS}

The purpose hereof is an ex-post evaluation of the implementation mechanism of LEADER on the level of local action groups in V4 countries (in the programme period 2007-2013). The evaluation focuses on the extent to which compliance with the seven basic functions of the programme was supported. The first step was obtaining statistical data, theoretical knowledge and legislative framework on the implementation of LEADER in all V4 countries. After that, a comparison was performed.

The subject of the comparison was quantitative aspects of the implementation of the LEADER mechanism in V4 countries at the end of the programme period 2007-2013 compared to the planned stage of the Rural Development Programmes.

The second step was the development of an evaluation framework for the mechanism of the LEADER approach implementation, based on the methodology developed by Tvrdoňová (2014). Another important methodological step was the definition of the seven basic functions of LEADER and allocation of success criteria (benchmarks) to them. 
Basic programme functions:

1) Integrated approach: benchmarks: - local development strategy supports the synergies of interests and needs of different sectors operating in the territory (geographical, social and economic);

2) Cooperation: benchmarks: - coordination among actors leads to effective and optimal allocation of resources, mutual communication of all partners within a transparent environment;

3) Innovation: benchmarks: - innovative management of local resources, decision-making process in LAG is free and flexible;

4) Networking: benchmarks: - actors at all three levels are clearly identified, active communication and awareness among individual actors;

5) Bottom-up approach: benchmarks: - local actors with adequate training hold leading positions, rate of usage of local resources;

6) Partnership approach (partnership between three sectors) among Visegrad countries: benchmarks: - partnership consists maximum $50 \%$ of public sector and minimum $50 \%$ of private and civic sector, representatives of all three sectors are involved in the decisionmaking process;

7) The regional strategy of local development: benchmarks: - strong identity of local inhabitants, territorial homogeneity regarding natural conditions, common history, cooperation, definition and achievement of common objectives.

Their presence represents the optimum status of the programme implementation. Evaluation of success criteria - benchmarks in the form of Skype interviews on the national level of LAGs (management of the national LAGs network in Poland, Hungary, the Czech Republic and Slovakia). The evaluation was performed on the basis of a scale from 1 to 5 points. The ex-post evaluation then generated conclusions and recommendations.

\section{RESULTS AND DISCUSSION}

\section{MAS in V4 countries}

The LEADER system mechanism is based on local action groups operating in all EU Member States. They implement tasks in the area of rural development policies. The main purpose of the trilateral partnerships is to develop and implement (apply) Local Development strategies (LDS) in the given area (especially selection of projects eligible for funding support). Local 
action groups in V4 countries are not unified in respect of the area size, population and number of members involved in their activities. This diversity is manifested on the inland and international level.

LAG area, see Fig. 1, 2, 3 and 4, maybe a relevant factor affecting its activity. The big distances between partners within a group may prevent interactions, especially by personal contact, which are key for LEADER approach implementation. On the other hand, geographical closeness connected with smaller LAG areas may contribute to frequent meetings and contacts among the partnership members. In Hungary, the mean area of a partnership is the highest $\left(908.1 \mathrm{~km}^{2}\right)$. In Poland, the mean area per partnership is $804.5 \mathrm{~km}^{2}$. LAGs in the Czech Republic are considerably smaller in comparison to these countries. The mean area of a LAG is 469.1 $\mathrm{km}^{2}$ in the Czech Republic and 310,2 $\mathrm{km}^{2}$ in Slovakia. Big partnership areas exceeding 1,500 $\mathrm{km}^{2}$ are typical of Poland and Hungary. In the Czech Republic there is only a single group whose area exceeds $1,500 \mathrm{~km}^{2}$, while in Poland there are 41 and in Hungary 8 such areas. In Slovakia, where most LAG areas are below $500 \mathrm{~km}^{2}$, there is no partnership that is that big. In the case of this country, only 5 of the 29 functioning LAGs are bigger than $500 \mathrm{~km}^{2}$. The area covered by the largest Slovak partnership (LAG Horný Liptov) is $766.2 \mathrm{~km}^{2}$.

The Czech Republic is clearly dominated by small tri-sectoral partnerships, but unlike Slovakia, there are also partnerships here whose area exceeds $1,000 \mathrm{~km}^{2}$. In the Czech Republic, there are 7 such partnerships. The area of the largest (LAG Vladař) is $1,757.0 \mathrm{~km}^{2}$. In Poland and in Hungary the largest, albeit not dominant, group ranges between 500 and $1,000 \mathrm{~km}^{2}$. Hungary shows the lowest proportion of small partnerships of all V4 countries. Hungarian LAGs covering areas smaller than $500 \mathrm{~km}^{2}$ only represent $17.9 \%$ of all existing tri-sectoral partnerships. At the same time, this country has 5 LAG partnerships exceeding the area of 2,000 $\mathrm{km}^{2}$. The largest Hungarian partnership (MAG Bükk-Térségi) has the area of 2,551.3 $\mathrm{km}^{2}$. The largest LAG in Poland also covers more than 2,000 $\mathrm{km}^{2}$ each (there are 19 such groups). Most of the largest partnerships can be found in the northern part of the country (Zachodniopomorskie, Pomorskie, WarmiaMazury, Podlasie), for their regions and not too densely populated. The largest Polish group (LAG Partnerstwo Dorzecze Słupi) covers the area of $4,184.1 \mathrm{~km}^{2}$. In all V4 countries, the smallest LAG areas cover about $100 \mathrm{~km}^{2}\left(72.6 \mathrm{~km}^{2}\right.$ in Slovakia and $134.7 \mathrm{~km}^{2}$ in the Czech Republic).

The tri-sectoral partnerships existing in Visegrad countries also differ in the number of municipalities forming the LAGs. This difference is however mainly caused by the different 
administrative structure of each of the countries. Polish municipalities are much bigger than municipalities in the other three countries. This means the lowest mean number of municipalities per LAG in Poland. In Poland, there are 6 self-governing units per LAG on average, while in the Czech Republic and in Hungary these numbers are 36 and 32, respectively. In Slovakia, there are usually 18 self-governing units per LAG. In Poland, there are also LAGs covering a single municipality. Although these partnerships are not common, their very existence should be seen as a negative. In the case of such LAG, there is an increased risk of their activities depending on the public sector.

In addition, a tri-sectoral partnership limited to the territory of a single municipality does not fully permit implementation of the LEADER programme in the correct and effective manner. On the other hand, it needs to be noted that in the programme period (2014 - 2020) it is no longer possible to form a partnership consisting of a single municipality only. In harmony with the objectives of the Rural Development Programme (DRP) for 2014-2020 every LAG in Poland must now include at least two self-governing units.

LAGs existing in the Visegrad group countries also differ significantly in their populations. The highest mean population can be seen in Poland (50.5 thousand) and in Hungary (47.2 thousand). The smallest group populations can be seen in Slovakia where the mean population per partnership is 21.2 thousand. In the Czech Republic, the mean population per LAG is 35.0 thousand. Poland is the only Visegrad group country where more than 100 thousand citizens form a partnership. In the Czech Republic and in Hungary there is just one such group per country. What must be emphasized, however, is that RDP rules set the upper limit of the LAG population to 100 thousand. In Slovakia, the largest partnership populations do not exceed 80 thousand, although in this country, like in Poland, RDP permits LAG with the population of up to 150 thousand. Most Slovak LAGs include 10 - 20 thousand citizens. There are 29 Slovak groups but only 2 exceed the limit of 40 thousand citizens. In the case of the Czech Republic, Poland and Hungary the largest partnerships range between 20 and 60 thousand citizens. In addition, as already mentioned, Poland, in comparison to the other Visegrad countries, has the largest number of groups inhabited by more than 100 thousand people. In total, they are 24 in number and the largest two of them (LGD Partnerstwo Dorzecze Słupi i Stowarzyszenie Światowid) have populations of nearly 150 thousand. The largest group population in Hungary consists of 118.0 thousand citizens (LAG Del-Nyírség Erdőspuszták) and the largest group population in the Czech Republic is 101.3 thousand (LAG Posázaví). 
Table 1 The structure of LAGs in the Visegrad Countries - plan RDP 2007-2013

\begin{tabular}{|l|l|l|l|l|}
\hline & Czech Republic & Slovakia & Poland & Hungary \\
\hline $\begin{array}{l}\text { A number of } \\
\text { LAG }\end{array}$ & 112 & 25 & 300 & 50 \\
\hline $\begin{array}{l}\text { The Total area of } \\
\text { LAG (thous. km }{ }^{2} \text { ) }\end{array}$ & 43 & 12 & 153 & 41 \\
\hline $\begin{array}{l}\text { The total number } \\
\text { of inhabitants in } \\
\text { LAG (thous. } \\
\text { people) }\end{array}$ & 3,300 & 350 & 10,000 & 2,500 \\
\hline $\begin{array}{l}\text { Exemptions } \\
\text { related to the area } \\
\text { covered by Local } \\
\text { development } \\
\text { strategies }\end{array}$ & $\begin{array}{l}- \text { cities over 25 } \\
\text { thousand } \\
\text { inhabitants }\end{array}$ & $\begin{array}{l}\text { - towns over 20 } \\
\text { thousand } \\
\text { inhabitants }\end{array}$ & $\begin{array}{l}\text { - municipalities } \\
\text { over 5 } \\
\text { thousand } \\
\text { inhabitants }\end{array}$ & $\begin{array}{l}\text { - towns over 10 } \\
\text { thousand } \\
\text { inhabitants or } \\
\text { with a } \\
\text { population } \\
\text { density } \\
\text { exceeding 120 } \\
\text { people per km }\end{array}$ \\
\hline
\end{tabular}

Source: Rural development programmes 2017 - 2013 from the Czech Republic, Slovakia, Poland, Hungary

Figure 1 Local action groups in the Czech Republic

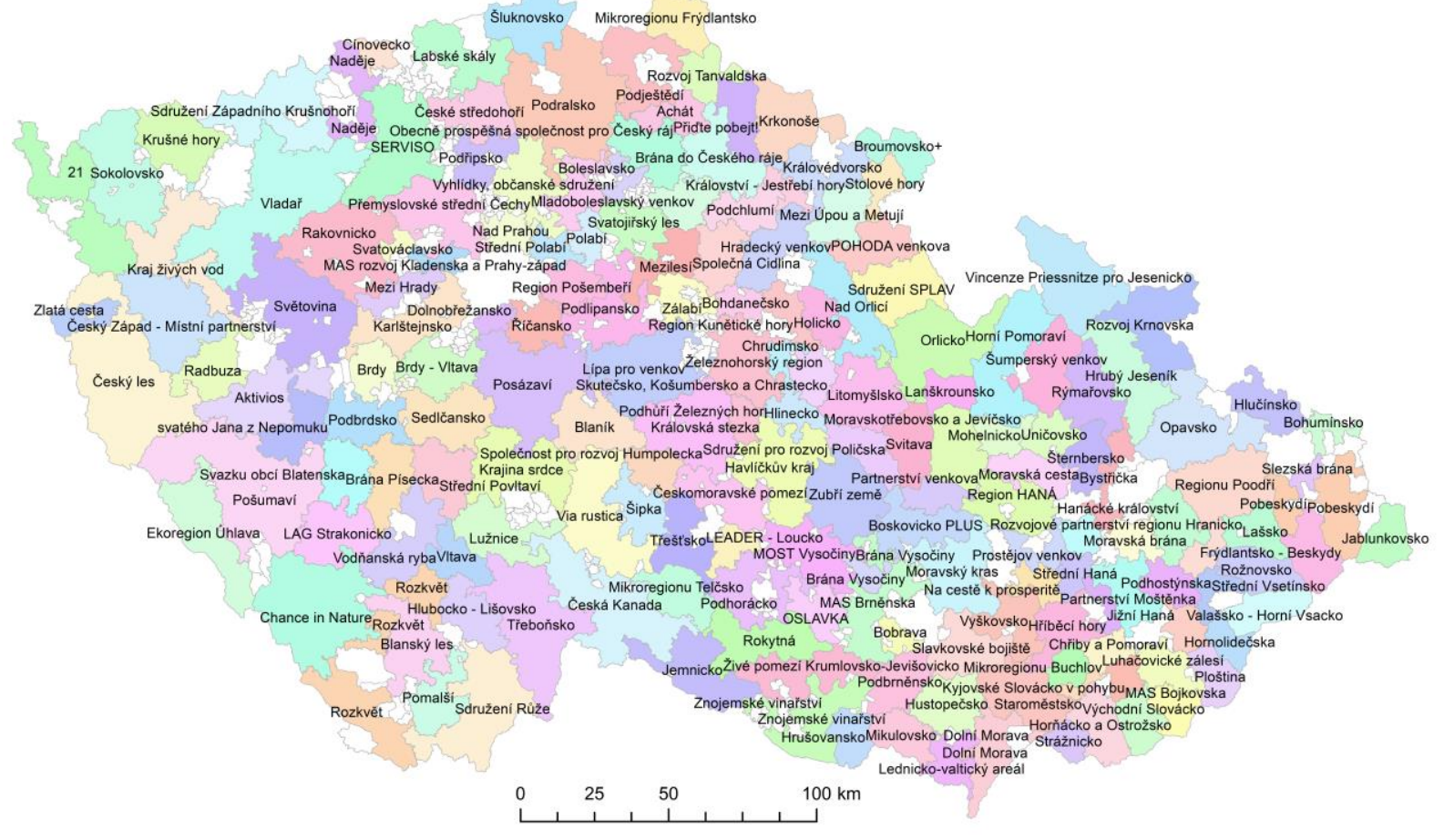

Source: Klufová, 2018 
Figure 2 Local action groups in the Slovak Republic

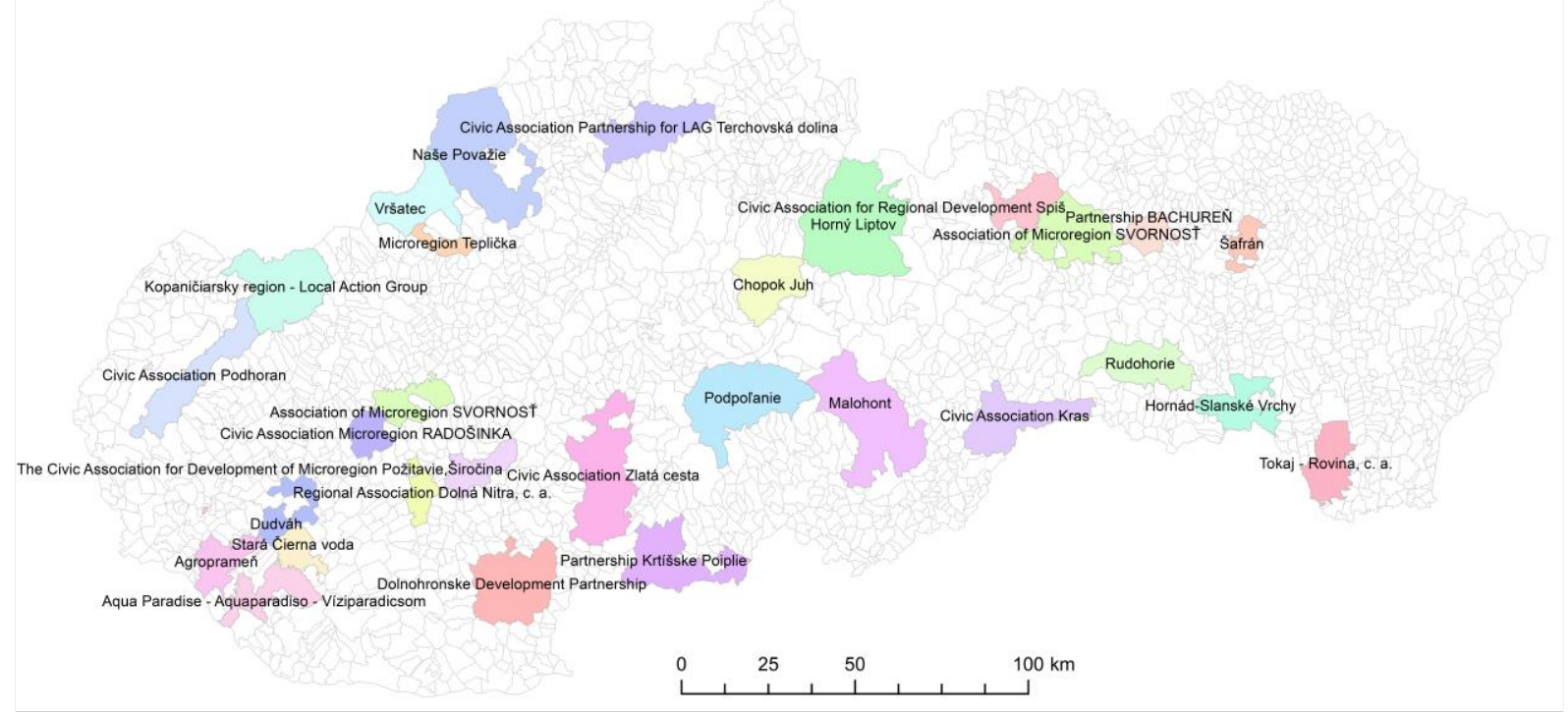

Source: Klufová, 2018

Figure 3 Local action groups in Poland

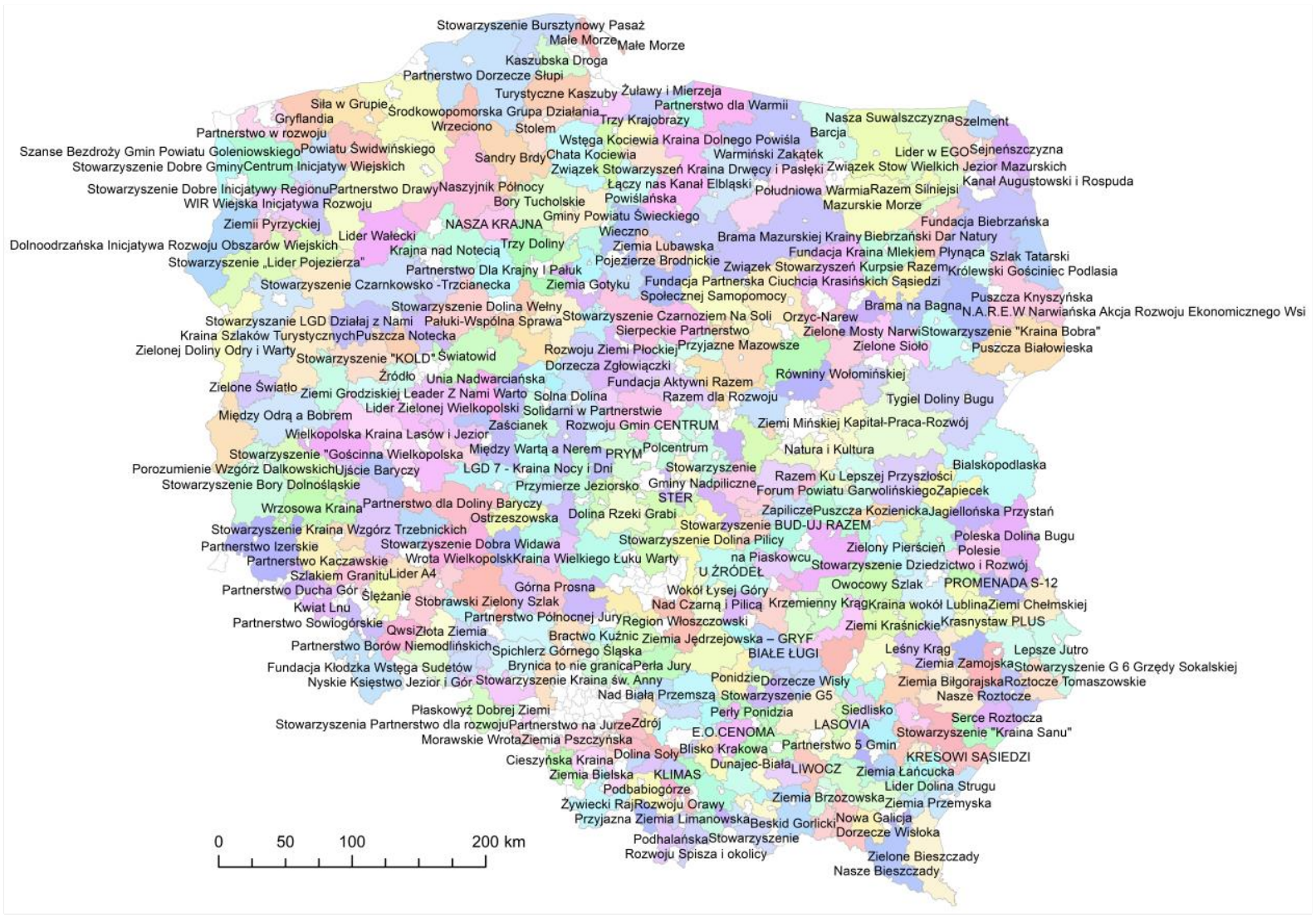

Source: Klufová, 2018 
Figure 4 Local action groups in Hungary

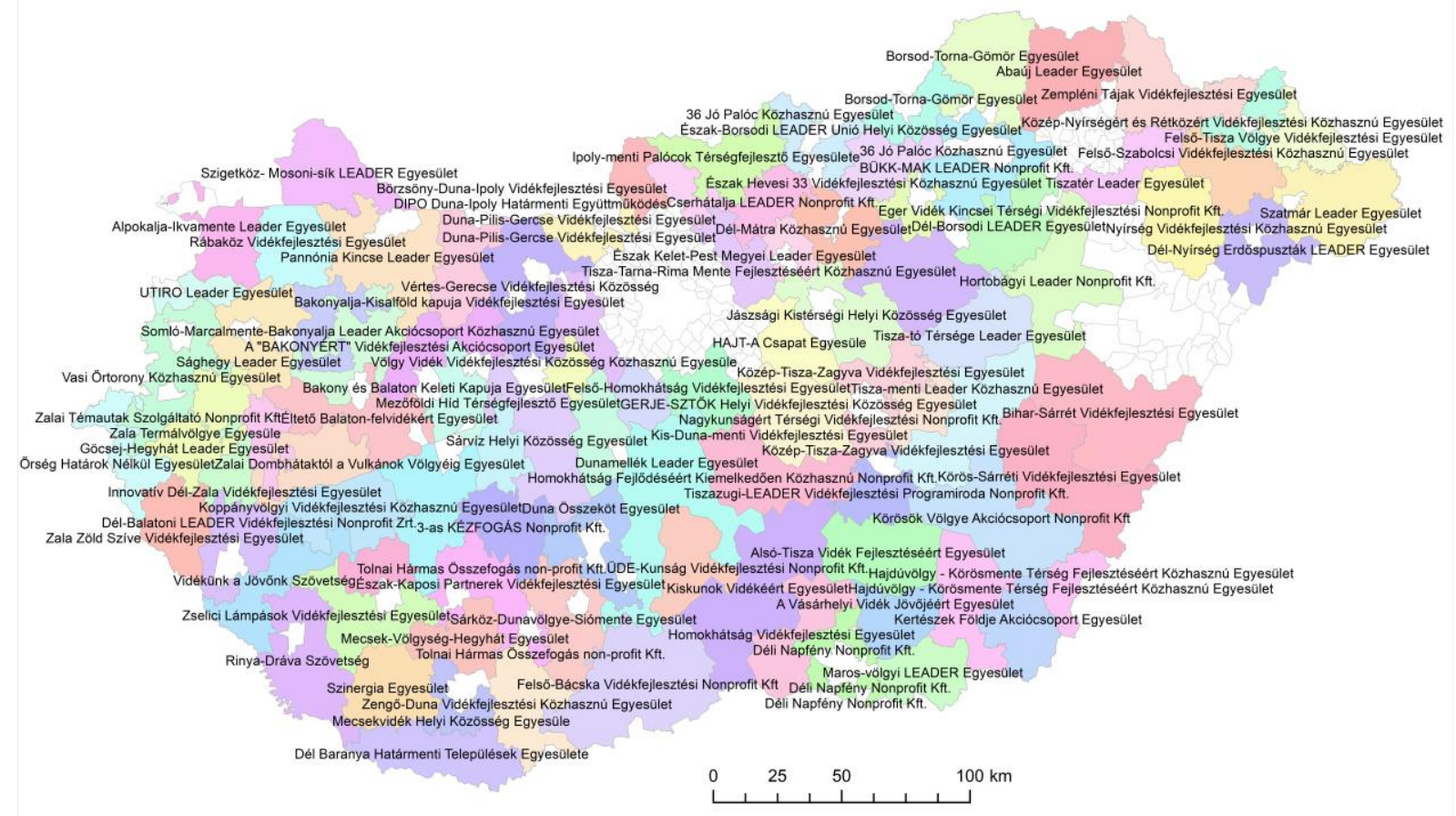

Source: Klufová, 2018

Local action groups, their functioning, and implementation of the LEADER programme are implemented on three levels: central, regional and local. The national level includes the control authority, the payment agency, and the certification body. The regional level responsibility for the LEADER programme implementation is within the executive body, which was only established in Poland in the programme period 2007-2013. On the local level, there are the very local action groups and the subsidy beneficiaries. The list of subjects responsible for implementation of the LEADER programme in V4 countries is shown in Tab.2.

Table 2 Entities and institutions involved in the LEADER approach implementation in 20072013

\begin{tabular}{|l|l|l|l|l|}
\hline Type of entity & $\begin{array}{l}\text { The Czech } \\
\text { Republic }\end{array}$ & $\begin{array}{l}\text { The Slovak } \\
\text { Republic }\end{array}$ & Poland & Hungary \\
\hline $\begin{array}{l}\text { Managing } \\
\text { Authority }\end{array}$ & $\begin{array}{l}\text { Ministry } \\
\text { of Agriculture }\end{array}$ & $\begin{array}{l}\text { Ministry } \\
\text { of Agriculture }\end{array}$ & $\begin{array}{l}\text { Ministry Agriculture and } \\
\text { of Rural Development } \\
\text { Ruratry Agriculture } \\
\text { Rural } \\
\text { and }\end{array}$ & $\begin{array}{l}\text { Ministropment } \\
\text { Developmen }\end{array}$ \\
\hline $\begin{array}{l}\text { Implementing } \\
\text { Authority }\end{array}$ & - & - & $\begin{array}{l}\text { Regional } \\
\text { Governments }\end{array}$ & - \\
\hline Paying Agency & $\begin{array}{l}\text { State } \\
\text { Agricultural } \\
\text { Intervention } \\
\text { Fund }\end{array}$ & $\begin{array}{l}\text { Agricultural } \\
\text { Paying Agency }\end{array}$ & $\begin{array}{l}\text { The Agency } \\
\text { for Restructuring } \\
\text { and Modernisation } \\
\text { of Agriculture }\end{array}$ & $\begin{array}{l}\text { Agricultural and } \\
\text { Rural } \\
\text { Development } \\
\text { Agency }\end{array}$ \\
\hline $\begin{array}{l}\text { Certification } \\
\text { Body }\end{array}$ & $\begin{array}{l}\text { Supreme Audit } \\
\text { Office }\end{array}$ & Deloitte Audit & $\begin{array}{l}\text { General Inspector } \\
\text { for Treasury Control }\end{array}$ & KPMG Hungary \\
\hline
\end{tabular}

Source: The data found on The European Network for Rural Development website(http://enrd.ec.europa.eu) 


\section{Quantitative Aspects of LEADER Mechanism Implementation in V4 Countries}

Another part of the results mainly focuses on the quantitative aspects of the LEADER mechanism implementation in Visegrad countries, analysing not only the number of the formed LAGs, their total area and populations, but also use of the funds allocated to the programme. The result indicator for this analysis is expressed as the percentage represented by the relationship between the actual value of the item and the value expected by RDP 2007 - 2013. It needs to be emphasized that in all V4 countries the real effects of the LEADER approach (implementation), with just a few exceptions, are much higher than expected in the Rural Development Programme at the beginning of the programme period 2007-2013. Considering the number of the formed tri-sectoral partnerships their total area and populations, Visegrad countries are clearly characterized by a high level of performance in the context of the LEADER programme implementation. In each of these countries, the LEADER approach implementation phenomenon is much more widely spread than originally expected. In nearly all Visegrad countries, except for the Czech Republic, the number of LAGs is higher than expected in RDP. It needs to be noted, though, that in the case of the Czech Republic the number of partnerships selected for funding (111) approaches the original goal of RDP (112). Another fact is that in the Czech Republic there are also groups whose activities are not directly funded from the European Agricultural Fund for Rural Development (there are together 59 such partnerships). The highest effectiveness of LAG formation can be observed in Hungary where the number of the formed partnerships (95) reached nearly double the original expectation (50). Poland achieved and even exceeded the objectives concerning LAG. At the end of 2013, Poland had in total 336 functioning LAGs (RDP expected 300 LAGs). Poland is the Visegrad as well as EU country with the largest number of tri-lateral partnerships. Slovakia has the lowest number of partnerships of all those countries implementing the idea of the LEADER programme - only represented by 29 LAGs. It should not be forgotten, though, that the low number of partnerships in Slovakia is the consequence of the very Rural Development Programme expecting only 25 LAGs to be financed from the European Agricultural Fund for Rural Development.

In most Visegrad countries, except for Slovakia, the LEADER programme implementation applied to an area larger than originally expected by RDP. Like in the case of the number of trisectoral partnerships selected for funding in relation to the total area used by LAG the highest index value was recorded in Hungary. In this country, the area with the LEADER approach implemented in more than double the original assumption. The same situation is in Poland where the total area used by the partnerships is much bigger than targeted by RDP, see Tab. 3 . In the Czech Republic, the functional groups selected for funding by the European Agricultural Fund for Rural Development cover an area about $20 \%$ larger than originally expected. On the 
other hand, Slovakia did not manage to achieve the expected area covered by the LEADER programme. In this case, the total area to which the LEADER partnerships apply is $25 \%$ smaller than expected by RDP.

In comparison to the areas used by LAGs in the individual V4 countries, it needs to be noted that these countries show changes in their level of coverage of their partnership relations in the three sectors. In relation to the total country, area LAGs cover the largest proportions in Poland and in Hungary. In Poland, the local partnerships cover up to $94.2 \%$ of the country area, and in Hungary, they cover $92.7 \%$. The lowest coverage is recorded in Slovakia where local partnerships only cover $18.3 \%$ of the total country area. In the Czech Republic LAGs subsidized from the European Agricultural Fund for Rural Development cover 66.0\% of the total county area. It must be noted, though, that in the Czech Republic there are groups not financed in the context of the Rural Development Programme. If these local partnerships are included, then LAGs cover about $90.0 \%$ of the area of the Czech Republic. In terms of a conclusion, in the case of Poland, Hungary, and the Czech Republic implementation of the LEADER programme in the years 2007-2013 certainly is a widespread phenomenon, while in Slovakia it only covers a relatively small part of the country.

Table 3 The results of the LEADER approach implantation in the Visegrad Countries in 20072013

\begin{tabular}{|l|l|l|l|l|l|l|}
\hline & \multicolumn{2}{|l|}{ Number of LAGs } & \multicolumn{2}{l|}{ Overall area of LAGs } & \multicolumn{2}{l|}{$\begin{array}{l}\text { The number of } \\
\text { Inhabitants in LAGs }\end{array}$} \\
\hline & Total & $\begin{array}{l}\text { Result } \\
\text { indicator } \\
(\%)\end{array}$ & Total $\left.\mathbf{( k m}^{2}\right)$ & $\begin{array}{l}\text { Result } \\
\text { indicator } \\
(\%)\end{array}$ & $\begin{array}{l}\text { Total } \\
\text { (thousand } \\
\text { people) }\end{array}$ & $\begin{array}{l}\text { Result } \\
\text { indicator } \\
(\%)\end{array}$ \\
\hline $\begin{array}{l}\text { The Czech } \\
\text { Republic }\end{array}$ & 111 & 99 & 52 & 121 & 4 & 117,9 \\
\hline $\begin{array}{l}\text { The Slovak } \\
\text { Republic }\end{array}$ & 29 & 116 & 9 & 75 & 615 & 176 \\
\hline Poland & 336 & 112 & 294 & 193 & 19 & 185 \\
\hline Hungary & 95 & 190 & 86 & 210 & 5 & 179 \\
\hline
\end{tabular}

Source: RDP 2007-2013 for the Czech Republic, Slovak Republic, Poland, Hungary and website (https://enrd.ec.europa.eu/)

\section{Evaluation of Key Functions of LEADER Programme}

The scoring system for evaluation of the key functions of the LEADER programme helped identify and compare a) the integrated approach, b) cooperation, c) innovation, d) networking, e) the bottom-up approach, f) partnership (of three sectors) between Visegrad countries and g) regional strategy of local development. The scale consisted of 5 points with 5 corresponding to full application of the above-mentioned features in each country. 
The integrated approach, including implementation of multiple events (in comparison to the traditional industry policies), was best scored in Poland. Cooperation understood as real interaction with the aim to achieve a real goal, was best scored in the Czech Republic and in Slovakia, see Table 4.

Lack of innovation is a common negative feature of MAS activities. Czech MAS obtained the best score in this area. As for the scoring of the bottom-up approach (i.e. implementation of ideas provided by local communities), it is rather unsatisfactory. The highest score was obtained by Slovakia (3), the Czech Republic followed (2) and Poland and Hungary were the worst (1).

The distinctive feature of local action groups in V4 countries is the formation of tri-sectoral partnerships, where Slovakia obtained (3) score points, the Czech Republic and Poland (2) and Hungary (1). In the case of Hungary, the situation was encountered where the involvement of all three partners in formation of new LAGs was neglected and minimized.

According to the qualitative evaluation by the management of the national networks of the local action groups the highest score for the key LEADER programme functions were obtained by Slovakia (20), followed by the Czech Republic (16), Poland (15) and Hungary (13).

Table 4 Evaluation of key features of the Leader approach in the V4

\begin{tabular}{|c|c|c|c|c|}
\hline \multirow[t]{2}{*}{ Key features } & & & & \\
\hline & $\begin{array}{l}\text { The Czech } \\
\text { Republic }\end{array}$ & $\begin{array}{l}\text { The Slovak } \\
\text { Republic }\end{array}$ & Poland & Hungary \\
\hline $\begin{array}{l}\text { Integrated } \\
\text { approach }\end{array}$ & 1 & 3 & 3 & 2 \\
\hline Cooperation & 3 & 3 & 2 & 2 \\
\hline Innovation & 2 & 1 & 1 & 1 \\
\hline $\begin{array}{l}\text { Relationship } \\
\text { forming }\end{array}$ & 3 & 3 & 2 & 3 \\
\hline $\begin{array}{l}\text { Bottom-up } \\
\text { approach }\end{array}$ & 1 & 3 & 1 & 1 \\
\hline $\begin{array}{l}\text { Local Public- } \\
\text { private } \\
\text { partnership }\end{array}$ & 2 & 3 & 2 & 1 \\
\hline $\begin{array}{l}\text { Area-based } \\
\text { local } \\
\text { development } \\
\text { strategies }\end{array}$ & 4 & 4 & 5 & 3 \\
\hline Total & 16 & 20 & 15 & 13 \\
\hline
\end{tabular}

Source: own research 


\section{CONCLUSION}

The programme period 2007-2013 was marked by the significant unification of the main principles, objectives, and implementation of the LEADER programme. However, the individual EU countries differ in compliance with the particular detailed implementation rules. This depends on the specific development conditions, which are different in each country (the legal and administrative context, the specifics of the rural areas etc.). Differences can also be observed in the Visegrad countries, including both quantitative and qualitative aspects of the LEADER approach implementation.

Because of the above-mentioned differences, the Visegrad group countries are clearly differentiated also in terms of the amounts of the financial contributions allocated for the LEADER approach implementation in the years 2007-2013. In each of these countries, the share of these funds in the total expenditures for the Rural Development Plan was below the EU mean. The analysed countries adopted various criteria for implementation of tri-sectoral partnerships (i.e. the maximum permitted population per LAG and exclusion of certain areas from LDS), which should be considered a manifestation of compliance with international conditions. In the case of all Visegrad group countries the actual implementation values - results of the LEADER approach (the number of the formed LAGs, their total area, and population), with just a couple of exceptions - are higher than specified in the Rural Development Plans of the individual countries.

Implementation of the LEADER programme in V4 countries appears much more widespread than originally expected. The results were most largely exceeded in Hungary and in Poland. In the Czech Republic, in addition to LAGs directly subsidized from the European Agricultural Fund for Rural Development, there are also partnerships not selected for funding in the context of the Rural Development Plan. The Visegrad Group countries, except for Slovakia, are characterized by large coverage of their territory with tri-lateral partnerships pursuant to the LEADER principle. In the case of Slovakia, the low value of this indicator may be justified by the low number of the formed LAGs, as a consequence of the rules of the RDP.

The Visegrad Group countries distinguish themselves by a large variety with regard to the effectiveness of the fund incurred for the purpose of the LEADER programme implementation. Before the end of 2013 the largest funds allocated for the LEADER programme implementation were incurred in the Czech Republic and for that reason, the country was recognized as one of the top EU countries in this respect. LAGs active in the Visegrad countries are clearly heterogeneous with regard to their populations and numbers of their members involved in their 
activity. Despite these differences, there are a couple of common characteristic features of the tri-lateral partnerships in the individual countries.

In their qualitative evaluation of the management of the individual national LAG networks emphasized the major obstacles found (errors of the LEADER programme), such as the low trust among the parties involved in the development process (the Czech Republic), insufficient involvement of the business sector (Hungary), administrative barriers (Poland), low level of participation in the integrated projects and privileged position of the public sector in the fund allocation (Slovakia).

The recommendation for future is to promote cooperation in the community-led local development (CLLD) context, Member States could give priority in their selection procedure to LAGs which have integrated cooperation into their local development strategies. They could, for example, make the quality of LAG proposals for co-operation a criterion for selecting their strategies. Having in mind that, in the system of shared management, not all rules can be harmonised on a European level, it is moreover recommended to make efforts to harmonise the procedures and definitions for LEADER cooperation as far as possible at MS level. This is especially valid as regards inter-territorial co-operation in MS with regional development programs, but also between MS involved in transnational co-operation. The use of other tools for territorial co-operation offered by the ESIFunds.

\section{Acknowledgements}

This paper represents a partial result of the project IGS16A1 of the internal grant EF JU: The Impact of LAGs on regional development in the Visegrad Group countries.

\section{REFERENCES}

Bache, I., \& Flinders, M (2004). Multi-level Governance. Oxford, Oxford University Press. Brković, D., \& Hamada, M. (2013). Evaluation of the LEADER Program in Slovak Republic Case Study LAG "Vršatec". Агрознање, 14(2), 251-259.

Copus, A., Shucksmith, M., Dax, T., \& Meredith, D. (2011). Cohesion Policy for rural areas after 2013. Studies in Agricultural Economics, 113, 121-132.

European Commission (2006). LEADER Approach - basic guidelines [online]. Retrieved from http://ec.europa.eu/agriculture/rur/leaderplus/pdf/library/methodology/leader_approach_ sk.pdf.

Fałkowski, J. (2013). Political accountability and governance in rural areas: Some evidence from the Pilot Programme LEADER+ in Poland. Journal of Rural Studies, 32, 70-79.

High, C., \& Nemes, G. (2007). Social learning in LEADER: exogenous, endogenous and hybrid evaluation in rural development. Sociologia Ruralis, 47(2), 103-119.

Kovács, A. D. (Ed.) (2004). New Aspects of Regional Transformation and the Urban-Rural Relationship. Centre for Regional Studies of the Hungarian Academy of Sciences, Pecs, Hungary. 
Milotová, B. (2011). Implementácia prístupu LEADER na Slovensku: kritický pohl’ad. In. V. Klímová, V., Žítek, V. (Eds.) XIV. mezinárodní kolokvium o regionálních védách: sbornik príspěvkỉ Bořetice, 22nd -24th June 2011 (pp. 244-252). Brno: Masarykova univerzita.

Navarro, F. A., Woods, M., \& Cejudo, E. (2015). The LEADER Initiative has been a Victim of Its Own Success. The Decline of the Bottom-Up Approach in Rural Development Programmes. The Cases of Wales and Andalusia. Sociologia Ruralis, 56(2), 270-288.

Oedl-Wieser, T., Strahl, W., \& Dax, T. (2010). The LEADER programme 2007-2013: refocusing towards agriculture-oriented activities as a consequence of 'mainstreaming' innovative rural action in Austria. In 118th EAAE Seminar "Rural development: governance, policy design and delivery", Ljubljana (Slovenia).

Pollermann, K., Raue, P., \& Schnaut, G. (2014). Opportunities for a participative approach in rural development: Findings from LEADER in Mecklenburg-Vorpommern and the requirements for Community Led Local Development. Landbauforschung - Appl Agric Forestry Res, 64 (3-4), 127-138.

Póla, P., Chevalier, P., \& Maurel, M. C. (2015). A LEADER akciócsoportok és partnerségi hálózatok müködésének tanulságai Baranya megyében. Tér és társadalom, 29(1), 175194.

Teilmann, K., \& Thuesen, A. (2014). Important Types of LAG-Municipality Interaction When Collaborating on Rural Development Lessons from Danish LEADER LAGs. International Journal of Rural Management, 10(1), 21-45.

Thelen, W. (1999). The Hessen regional programme for rural areas and LEADER,Contribution to the LEADER Seminar in Gesves (Wallonie-B) Internetseite Rural Europe [online]. Retrieved from http://ec.europa.eu/agriculture/rur/LEADER2/rural-e n/plr/mainstream/index.htm\#4-2.

Zajda, K. (2014). Problems of functioning of Polish local action groups from the perspective of the social capital concept. Eastern European Countryside. 20(1), 73 - 97. 